\title{
Determinants of self-preservation behavior Russian population
}

\author{
Valentin Babintsev ${ }^{1}$, Svetlana Vangorodskaya ${ }^{1}$, and Galina Gaidukova ${ }^{1, *}$ \\ ${ }^{1}$ Belgorod State University, 308015, Ulitsa Pobedy, 85, Belgorod, Russia
}

\begin{abstract}
On the basis of these semi-structured interviews conducted in the autumn of 2018 with the participation of residents of central Russia, the determinants of self-preservation behavior of Russia's population are identified in the context of a complex interaction of social and cultural traditions and innovations. Particular attention is paid to the analysis of behavioral patterns in the field of health, deterministic mental peculiarities of the Russians. Considers the environmental conditions in the place of residence, genetic predisposition to certain diseases, nutrition quality to be the main factors that have the greatest impact on individual health indicators, and also the presence (absence) of financial resources. The study revealed the ideas of Russians about the causes of "male supermortality", which caused abnormal gender imbalances in mortality rates of the Russian population. It is concluded that the government's policy with regard to the formation of optimal models of self-preservation behavior should, first of all, to focus on the development and implementation of appropriate measures in relation to working-age men, and include not only the "prohibitive" and restrictive measures, but also activities to change the value-motivational foundations of self-preserving behavior.
\end{abstract}

\section{Introduction}

In the context of a dynamically changing social reality [1], a high rate of transformation of behavioral models of various groups of the Russian population becomes the norm. They, as a rule, bizarrely combine the elements of retroarchaic, defined by traditional value-semantic complexes, and the phenomena generated by modern postmodern reality. One effect of such a combination is the instability behaviors constant change dispositions occurrence, distribution and disappearance of new trends. This is characteristic, practically, for all ways of life, including self-preserving behavior, as a set of practices aimed at maintaining health and increasing the duration of a full life [2].

It is quite obvious that, in a multicultural social environment, which is typical for modern Russia, we should talk about the plurality of social behavior trends [3]. But so far many problems associated with their identification and interpretation of the problem remain unresolved. In particular, they include the problem of social determinants of self-preserving behavior $[4,5]$, without identifying which it is impossible to determine its consequences for the individual and society.

* Corresponding author: g_gaidukova@bsu.edu.ru 
Accordingly, the purpose of this article is to analyze the determinants (factors) that determine the behavior of the self-preservation of the Russian population in the context of a complex interaction of social and cultural traditions and innovations.

\section{Materials and methods}

The main research method is a series of semi-structured interviews conducted in September-November 2018 with the participation of 35 residents of the Belgorod region, one of the regions of Central Russia, aged 19 to 80 years. Respondents were selected using the "snowball" method. The main purpose of a series of qualitative interviews was the verbalization prevailing determinants related to the preservation and strengthening of individual and public health.

\section{Results and discussion}

Reforming the health care system in Russia, the implementation of health care programs for the population has not yet yielded tangible results. As the data of quantitative and qualitative studies show, a significant part of the Russian population pays little attention to systematic care for their health, preferring to postpone a visit to the doctor until the last, and in case of illness - to self-medicate. In particular, the results of a mass survey conducted in 2018 in 9 regions of Central Russia ( $N=1067$ ) showed that only $25.7 \%$ of Russians go to a municipal polyclinic or hospital in case of illness, and almost every second of the respondents does so if self-treatment does not bring the expected results (see table 1).

Table 1. Distribution of answers to the question «What do You do when you get sick?» (in \%)

\begin{tabular}{|r|c|c|}
\hline 1 & I apply to the municipal city polyclinic, hospital & 25,7 \\
\hline 2 & I apply to a paid (non-state) polyclinic or hospit & 9,6 \\
\hline 3 & I appeal to traditional healers, alternative medic & 0,7 \\
\hline 4 & I treat myself & 13,5 \\
\hline 5 & I begin to be treated myself, and if there are no improvements, I contact a doctor & 44,4 \\
\hline 6 & I don't do anything, I let everything «take its course» & 6,1 \\
\hline & Total & 100,0 \\
\hline
\end{tabular}

In these conditions, it was important to find out the value-motivational foundations and attitudes of the population in relation to their health. Particular attention was paid to the analysis of behavioral patterns in the field of health, determined by the mental characteristics of Russians and those "cultural tools" that an individual receives from society.

It should be noted that many domestic and foreign studies emphasize the predominant role of the environmental factor as one of the main determinants of public and individual health [6]. This was also confirmed by the results of focus group interviews, during which, answering the question "What do you think, what factors have the greatest impact on human health?" representatives of all age groups overwhelmingly put the environmental situation in the place of residence in first place: "If we consider our region, then this is ecology and genetics, because if a person moved to another area, then he might have those diseases, or they would not start to develop" (woman, 20 years old, student); "... in the first place ecology. That is why people aged try to move to the periphery, to cleaner places, closer to the forest ..." (woman, 47 years old, deputy head of the clinic doctor); "Ecology. 
Such a bad environment, like ours, is nowhere to be found. Hence all the diseases" (woman, 77 years old, pensioner).

According to the respondents, heredity (a genetic predisposition to certain diseases) has an equally significant impact on the state of health: "I think this is heredity. If you get any kind of illness, it will be with you ... " (man, 24 years old, unemployed); "I have inherited hypertension, from which I have nowhere I can't go. And my mother, she had inherited ... " (woman, 40 years old, economist); "You can't get away from heredity, the most important thing seems to me" (man, 31 years old, security officer); "Genes are the most important thing" (man, 70 years old, pensioner, regional center); "Nobody canceled the inheritance. This is one of the main factors nevertheless" (woman, 67 years old, pensioner).

Respondents put food quality in third place ("The main thing that affects health is products. Products created by people are chemical compounds, and this leaves its mark. And against this background, the same heredity may appear. It could be hidden, and you would never know about it, and then ate some product pumped with an antibiotic, and it provoked the disease ..." (man, 24 years old, unemployed)), and the fourth place in the aggregate of elections was shared by the politician State and quality of medical services: "We have low social security and the healthcare system is not working in the same way. We sometimes health minister comes out and says that the level of AIDS in the country only increases. That is, she acknowledges her impotence, and does not try to do anything. And it affects a lot" (man, 20 years old, student); "Abroad, no one will tell a person that he needs to make oak bark in order to lower the pressure. He will be prescribed a drug and sent to a pharmacy. And they will not collect money for an expensive operation like ours, using the First Channel " (man, 20 years old, student).

As one of the most important factors, which unites all of the above, and determining the possibilities of man in relation to the preservation and strengthening of their own health, respondents indicated material (primarily financial) resources: "Finance is everything, a person can go for treatment anywhere, he can buy good products, etc." (man, 31 years old, security officer); "More money means more opportunities. You can pay for the gym, afford more expensive, environmentally friendly products " (man, 21 years old, student); "If you are a state employee, then it's hard for you to buy vegetables all year long. Yes, in the summer you can dig something up by the season, and the rest of the time it is very expensive ..." (woman, 20 years old, student).

Approval of the respondents correlate with the findings of Russian and foreign researchers engaged in the study of the major determinants that affect health outcomes [7, 8].

In the framework of the interview, it was important to identify the ideas in the public mind about the reasons for the low life expectancy of Russian men. Given the important role of alkogolezavisimyh deaths in Russia [9-12], which, according to the Organization for Economic Cooperation and Development (OECD, make up 30.5\% of the total number of deaths in Russia [13], it was logical to assume that in their answers, respondents in the first place to put it is the presence of Russian men of bad habits (and, first of all, alcohol abuse). This reason was really voiced by the majority of respondents (both by women and by the men themselves): "The man worked a hard day — I want to drink and relieve stress. And so every time ..." (man, 21 years old, student); "Our men drink a lot. Many of my friends Friday have been waiting all week to get drunk to an unconscious state " (man, 31 years old, security officer); "It's not in vain that in Russia in Russia Friday is called the day of a faceted glass" (woman, 47 years old, deputy head of the clinic's doctor); "Our men drink a lot. Historically, it happened " (man, 70 years old, pensioner).

It is necessary to underline the emotional background that accompanied the above statements. The majority of respondents showed more sympathy than condemning attitude to this addiction, stressing that alcohol abuse is primarily the result of great emotional stress 
that accompanies the life of Russian women in the new social and economic realities: "In our time, it is the pursuit of career success, and it's becoming harder and harder, because the staff requirements are growing in our country and the whole world. And if a man in the mind laid, that he - getter, the head of the family, then it is very painfully affected by factors such as dismissal, his women are more salary, it affects that 20 years he begins to drink " (woman, student).

During the interview, the woman has repeatedly stressed that the low life expectancy of Russian men is largely due to the fact that the post-employment and retirement Russian men can 't "find himself" and thus (perhaps not always consciously) to launch the "program self-destruction". There is probably a rational element in these considerations, since data from studies conducted in recent years confirm the fact that it is the combination of women's economic and domestic employment that creates favorable conditions for improving health indicators and extending the terms of a full life, which distinguishes them from men who for the most part, they are limited only to professional activities [14].

Among the cultural and historical characteristics of self-preservation behavior of Russian men respondents cited neglect of his health: "I once went to a clinic, and there was a man, which even medical policy was not, he was the first time in 50 years, came to the hospital and then - his wife dragged" (man, 21 years old, student); "Injury ... Men are more prone to it. Moreover, a Russian man who is always attracted to some kind of adventure: jumping from a bridge, driving on motorbikes and so on" (woman, 21 years old, sales assistant); "Because they (men) do not take care of themselves. They use synthetic beer, drink vodka. Do not go once again to clinics. And as already a critical condition, then already ... And so - no. You can't get a physical examination. A woman stabbed something - she was already worried and ran to the clinic, while a man stabbed something - "Maybe it will pass?" (woman, 60 years old, pensioner).

Paying attention to the passivity and indifference of men about their health, the respondents tend to explain it is primarily mental problems of Russians: "There is no tradition in our culture to take care of our health. I have the opportunity to send my mother to rest in a sanatorium every year. But to force her is simply impossible. She considers this a waste of time and money and refuses to go: "I'd better sit with my grandchildren and work in the country" (man, 29 years old, director of the sanatorium); "The historically established way of life ... We are not used to monitoring our health, to be examined on time ..." (man, 70 years old, pensioner).

Formed throughout Russian history, these units continue to dominate the minds of most of the population of Russia, predetermining a passive attitude to various aspects of private life. That is why in the statements of the respondents there was a direct or indirect request for the return of the "strong fatherly hand" of the state to all spheres of public life. This request, which is manifested, first of all, to "establish clear rules of the game that are valid for all and monitor their implementation" [15], as a rule, prevailed in the responses of older respondents in a comparative assessment of the current healthcare system and health protection system in the Soviet period: "In the USSR, state policy was more focused on a healthy lifestyle: posters hung everywhere, charging was carried out at enterprises. Yes, people are working hard, but this promotion of unhealthy lifestyles, as it is now, the time was not into that. And now films and songs are aimed at this. And we look at them much more than before. Yes, and the psyche of people is different, someone will look and nothing, but someone will start smoking or taking drugs" (woman, 60 years old, pensioner); "They were healthier, because in addition to school they forced me to do something else, there were regular checkups ... (housewife); "There was a very strict control over the quality of products - State standards, Departments of technical control ..." (woman, 19 years old, student); "In Soviet times, such checks were .. All products are tested for quality. Now there is no way to control the quality of products. Therefore, in terms of control, in 
terms of product quality - in Soviet times it was much better" (woman, 67 years old, pensioner).

In these answers of respondents (especially the older generation), nostalgic notes are clearly traced, demonstrating regret for those times when the basis of public policy was a strong ideology and a common goal (making health care more meaningful), and people sincerely followed socialist values and lived with a sense of stability and confidence in tomorrow: "We were confident in tomorrow!" (man, 70 years old, senior citizen); “... There was no excitement that there would be no work, it was psychologically calmer" (woman, 80 years old, pensioner); "Previously, production was developed, work was and people themselves were interested in it, and there were no vacillations, there were no problems" (man, 26 years old, military man).

Even the numerous stresses that accompanied the Soviet period of Russian history, were presented by the respondents as a factor that had a positive impact on the health of generations past: "It seems, and the life they have been heavy, but still health was better. Was they more stress-resistant?" (man, 29 years old, director of the sanatorium); "I believe that the past generation was healthier. Because the people who endured all these tests were tempered. It's just that organisms have become stronger and more enduring" (woman, 65 years old, pensioner).

The arguments about the advantages of the Soviet period in terms of health promotion are very clearly indicated the existence of a collective consciousness of Russians paternalistic attitudes built on the belief that the state should take responsibility for maintaining the health of everyone.

\section{Conclusion}

Summarizing the analysis of qualitative interviews, we can make some general conclusions about the main determinants of an individual's health status of people in Russia. Most of the respondents put in first place among them the environmental situation in the place of residence, heredity (a genetic predisposition to certain diseases) and food quality. As one of the most important determinants that unites all of the above, and determining the possibilities of man in relation to the preservation and strengthening of their own health, respondents indicated material (primarily financial) resources. It is also significant that during the interview a very low level of personal activity was revealed, with which the majority of respondents associate the protection of their own health. In our opinion, this is evidence of the presence of paternalistic attitudes among Russians, reflecting the traditionally dominant role of the state in solving the problems of the individual. Formed throughout Russian history, these units continue to dominate the minds of most of the population of Russia, predetermining a passive attitude to various aspects of private life.

It can be concluded that at the current stage of development of the Russian society in the overall strategy of self-preservation behavior of the population is dominated by forms such as risky behavior (characterized by the absence of personal activity and the presence of harmful habits) and behavior associated with the need to receive medical care in extreme situations (manifested only when the symptoms of the disease or its development). Such forms of self-preserving behavior, as preventive behavior and behavior associated with disease control, have not yet become widespread, which is associated not only with the lack of opportunities, but also with the low real value of health in the minds of Russians and the lack of formativeness of collective attitudes towards preventive activities.

In these circumstances it is necessary to direct all efforts of the state, first of all, to change the patterns of behavior that have emerged under the influence of natural, landscape, political, cultural and historical factors that accompany the historical 
development of the Russian state and have a strong influence on the formation of modern models of self-preservation behavior.

Phenomena of the same order can also be attributed to the phenomenon of male supermortality, determined not only by the presence of bad habits, a greater risk appetite and less stress resistance, but also by the historically prevailing image of a Russian man as a warrior and earner, restrained by the emotions, who can sacrifice his life in name of the family, "king and Fatherland". It is this way, according to respondents, was a serious obstacle in the formation of mental self-preservation facilities in the minds of Russian men, for whom taking care of your health is a matter, not worthy of serious attention and conscious effort.

Based on this, the state policy regarding the formation of optimal models of selfpreserving behavior should, first of all, focus on the development and implementation of appropriate measures for the male population, in general, and men of working age, in particular. It should include not only "prohibitive" and restrictive measures, but also activities to change the value-motivational foundations of behavior with a reorientation to maintaining and strengthening health and expanding ways of spending leisure time in the direction of its more health-saving forms.

The article was carried out within the framework of the state task of the national research Belgorod State University for 2020, project No. 0624-2020-0027 «Socio-demographic determinants of rural development in the Central Chernozem economic region».

\section{References}

1. C. Williams, V. Chuprov, J. Zubok, Youth, risk, and Russian modernity (Taylor and Francis, London, 2018) doi: 10.4324/9781315198552

2. I.S. Shapovalova, S.A. Vangorodskaya, O.V. Shevchenko, S.V. Funikova, N.A. Mamatova, Opción 35, 148-161 (2019)

3. M. Fishbein, I. Ajzen, Predicting and Changing Behavior: The Reasoned Action Approach (Psychology Press, Taylor \& Francis Group, New York, 2010)

4. V.M. Shkolnikov, E.M. Andreev, M. McKee, D.A. Leon, Demographic Research, 28, 917-950 (2013) doi: 10.4054/DemRes.2013.28.32

5. S.A. Vangorodskaya, I.S. Shapovalova, Z.A. Bubyreva, Z. SGEM International Multidisciplinary Scientific Conference on Social Sciences and Arts 2, 745-751 (2014) doi: 10.5593/SGEMSOCIAL2014/B12/S2.095

6. E. McCulley, Pricila Mullachery, Daniel Rodriguez, Ana Diez Roux, Usama Bilal, BMJ Open, 9, 1-4 (2019) doi: 10.1136/bmjopen-2019-031176

7. A. Hajat, J.S. Kaufman, K.M. Rose, Arjumand Siddiqi, James C. Thomas, Am J Epidemiol, 173(2), 192-200 (2011) doi: 10.1093/aje/kwq348

8. S.H. Saydah, G. Imperatore, G.L. Beckles, Diabetes Care 36(1), 49-55 (2013) doi: $10.2337 / \mathrm{dc} 11-1864$

9. D. Khalturina, A. Korotaev, Alcohol and Alcoholism 50(4), 1-14 (2015) doi: 10.1093/alcalc/agv042

10. W.A. Pridemore, M.B. Chamlin, M.T. Kaylen, E. Andreev, Alcoholism: Clinical and Experimental Research 38(1), 257-266 (2014) doi: 10.1111/acer.12256

11. V.M. Shkolnikov, D.A. Leon, I. Danilova, Journal of Studies on Alcohol and Drugs 80(5), 501-502 (2019) doi: 10.1111/dar.13034.

12. D. Treisman, Economics of Transition 18(2), 281-331 (2010) doi: 10.1111/j.14680351.2009.00382.x 
13. Tackling harmful alcohol use: Economics and public health policy (Franco Sassi, ed. OEDS Publishing, OECD (2015) doi: 10.1787/9789264181069-en

14. S. Harper, Population Ageing 11, 213-216 (2018) doi: 10.1007/s12062-018-9227-5

15. S.V. Mareeva, Journal of Economic Sociology (Latvia) 3(1), 39-54 (2015) 